\title{
Economic value of community forest to local users : A case study from Barandabhar Protected Forest, Chitwan, Nepal
}

\author{
R. Lamichhane ${ }^{1 *}$, A. Sedhain ${ }^{1}$, and M. Maharjan ${ }^{1}$
}

\begin{abstract}
Barandabhar Protected Forest (PF) has provided numerous goods and services to the people living around the forest. Integrated evaluation of this PF along with its ecological and economic value is required for the conservation and sustainable management of its forest resource. The field study was carried out in two community-managed forests around the Barandabhar PF. Market Price Method and Contingent Valuation Method were used to estimate the use and non-use values of the forest. Determination of the local users' willingness to pay for sustainable management and conservation of the natural resources was done through Contingent Valuation Survey. It was administered to 142 users. Multiple Regression Model was used to analyze the factors affecting the users' willingness to pay (WTP) value. The WTP value for the conservation and sustainable management of forest was found to be affected by the income and gender of the users and their time to reach the forest. The study revealed that the women were more willing to pay for the environmental services provided by the forest. Based on the household $(\mathrm{HH})$ survey, the average $\mathrm{HH}$-consumption of the forest products (timber, fodder and fuelwood) was estimated to be worth of NRs. 5,246 (US\$ 46. 69) per HH per year and the specific use value of the forest was estimated to be NRs. 15,160,940 (US $\$ 134,931.82$ ) per year. The total WTP value for the sustainable management and conservation of the forests was estimated to be NRs. 1,341,153 (US\$11,936. 20) per year; the users' average WTP value for the conservation and sustainable management of the Barandabhar PF being NRs. 589 (US\$ 5. 24) per HH per year.
\end{abstract}

Key words : Contingent Valuation Method, economic valuation, goods and services, willingness to pay

$\mathrm{N}$ atural ecosystems provide a wide range of services and economic benefits for local livelihoods (Pant et al., 2012) and human wellbeing (MEA, 2005). Ecosystem goods and services are the benefits that people obtain from natural environment (MEA, 2005). Ecosystem provides essential goods such as food, fodder, fuelwood, timber and non-timber forest products (NTFPs) including medicinal plants on the one hand and various fundamental benefits such as soil production, erosion and control, climate regulation, water purification, bio-energy, etc. on the other hand. These benefits and services are very crucial for the survival of human beings and other organisms on the earth (MEA, 2003; de Groot et al., 2002; Villegas-Palacio et al., 2016). Ecosystem services are generated as a consequence of interaction and complex exchange between biotic and abiotic components of an ecosystem (Singh et al., 2002).

Nepal's forests are often described as "green wealth of Nepal" because of its significant contribution in the livelihoods of a large number of communities. Rural people depend on forest resources for their livelihoods by collecting

1 Institute of Forestry (IOF), Tribhuvan University (TU), Hetauda, Nepal *E-mail: rakshyalamichhane123@gmail.com 
biomass to meet their needs for firewood, fodder, leaf-litter, NTFPs and other forest products (Powell et al., 2002). Moreover, recreational, socio-cultural, regulating, provisioning and so on are the main ecosystem services provided by forests.

Ecosystem valuation can be defined as the valuation of the quantities of the goods and services provided by an ecosystem (Kumar and Kumar, 2002). There are numerous approaches used in ecosystem valuation studies. These include- measuring the direct costs of ecosystem services in explicit markets (such as the revenue from selling a ton of carbon), the productivity method (such as measuring the contribution that pollination makes to total farm-gate output), hedonic pricing estimates (using for instance, changes in real estate or other market process as a proxy for the value of the ecosystem services), travel cost method (which measures how much people had spent to visit protected parks), and contingent valuation method (CVM) through different kinds of WTP surveys or questionnaires ( Barbier et al. 2009).

$\mathrm{KC}$ et al. (2010) have examined the value of ecosystem services in the Baghmara Buffer Zone Community Forest of Nepal adopting the CVM. Similarly, Bhandari et al. (2018) have estimated the economic value of ecosystem services provided by the Panchase Protected Forest (PF) of Nepal using the CVM; the analysis revealed that the total annual economic value of the Panchase PF was NRs. 52. 2 million (US\$ 521,930. 00).

\section{Methodology \\ Study area}

The study was conducted in Barandabhar Protected Forest (PF) of Chitwan District of Nepal during December, 2018 May, 2019. The Barandabhar PF is located between $27^{\circ} 39^{\prime} \mathrm{N}$ and $27^{\circ} 46^{\prime} \mathrm{N}$ latitudes and between $84^{\circ} 28^{\prime} \mathrm{E}$ and $84^{\circ} 48^{\prime} \mathrm{E}$ longitudes. The Barandabhar forest block serves as a corridor for the movement of wild-lives (CNP, 2015). The Barandabhar Corridor Forest is the only existing corridor forest linking the Chitwan National Park (CNP) and the Parsa National Park of Nepal together with the Valmiki Tiger Reserve of India with the ecologically significant upland forests of the Mahabharat range. The forest situated north of the East-West Highway is managed by the District Forest Office, Chitwan as protected forest whereas that of the south is managed by the CNP as buffer zone (CNP, 2015). Encompassing over an area of 10,302 ha area, the Barandabhar forest was announced as the Barandabhar PF on $15^{\text {th }}$ Falgun, 2068 B. S.

The Barandabhar forest area has been divided into three management zones, namely i) impact zone, ii) intensive forest management zone and iii) core zone. The settlements outside the protected forest have been declared as impact zone which includes 17,453 HHs. Similarly, the intensive forest management zone is managed by 16 community forest (CF), 36 leasehold forest, and 3 religious forest management committees. The core zone covering an area of 6,922 ha has been set aside as the protected area for wildlife habitat and biological corridor. Purposive sampling method used to select two community forests (CFs) i.e. Panchakanya $\mathrm{CF}$ with the highest users and Jaldevi CF with the lowest users from impact zone. The Panchakanya CF, registered as community forest in 2068 B. S., lies within the Ratnanagar Municipality of Chitwan district; the total area of this CF is $197 \mathrm{ha}$, and covers $1,615 \mathrm{HHs}$. On the other hand, the Jaldevi CF, registered as CF in 2067 B. S., is located in Bharatpur Metropolitan of Chitwan district. It covers an area of 198 ha area and 1,275 HHs. Sal (Shorea robusta) and Sissoo (Dalbergia sissoo) are the dominant tree species found in both the CFs.

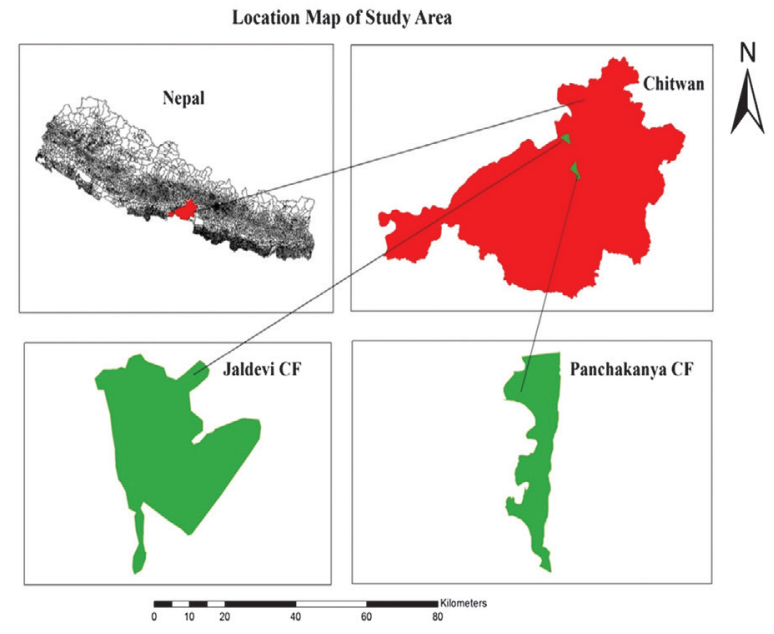

Figure 1 : Map showing the locations of the two selected community forests 


\section{Sample size sampling technique used}

Out of the total HHs covered by the two CFs, $5 \%$ $\mathrm{HHs}$ from each $\mathrm{CF}$ were taken for $\mathrm{HH}$ survey. Simple random sampling procedure was adapted to select the HHs.

Semi-structured questionnaire were used to acquire the information regarding the people's perception towards the forest. Out of the total 2,890 HHs covered by the two CFs, $142 \mathrm{HHs}$ ( 80 HHs covered by the Panchakanya CF and $62 \mathrm{HHs}$ covered by the Jaldevi CF) were selected randomly for $\mathrm{HH}$ survey. Prioritization of the goods and services from the CFs was done on the basis of the users' preferences. Market Price Method and Contingent Valuation Method were used to assess the economic value of the CFs. Two focus group discussions were organized with the various levels of stakeholders within the study area. Definition and description of the independent variables for the local users is given in table 1 .

\section{Prioritization of goods and services from the CFs}

For the users' preference ranking of the environmental goods and services, the ranking scores were calculated using the analytical technique of Reverse Method. In this method, the first choice will have the highest weighted value and the last choice will have the lowest weighted value. For example, if there are, altogether, 5 choices regarding the ecosystem goods and services to be prioritized and if a respondent gives first $\left(1^{\text {st }}\right)$ choice to one of them, then its weighted value will be 5 ; on the contrary, if a respondent gives last $\left(5^{\text {th }}\right)$ choice for any of the services, then its weighted value will be 1 . The average ranking score is calculated as :

$$
\begin{aligned}
& \text { Average } \\
& \text { ranking score }
\end{aligned}=\frac{\mathrm{X}_{1} \mathrm{~W}_{1}+\mathrm{X}_{2} \mathrm{~W}_{2}+\mathrm{X}_{3} \mathrm{~W}_{3}+\ldots+\mathrm{X}_{\mathrm{n}} \mathrm{W}_{\mathrm{n}}}{\text { Total no. of respondents }}
$$

Where, $\mathrm{W}=$ Weight of ranked position, $\mathrm{n}=$ no. of choice, and

$\mathrm{X}=$ Respondent's count for choice of answer

\section{Valuation of goods and services}

\section{a) Market Price Method}

Market Price Method (MPM) estimates the economic value of the goods or services provided by an ecosystem that are bought and sold in markets. It uses standard economic techniques for measuring the economic benefits from marketed goods and services. The market price method uses prevailing prices for goods and services, such as timber, fuelwood, non-wood forest products (e.g., mushrooms, berries, aromatic and medicinal plants, etc.) traded in markets. The price data can be easily obtained using the MPM as it only takes account of the use-values and marketed goods or services that have an actual price. So, we used MPM in this study. Market data are available only for a limited number of goods and services.

\section{b) Contingent valuation method}

True economic value of services may not be fully reflected by market price method in market transactions. Contingent Valuation Method (CVM), a form of "stated preference method", is used to estimate the economic values for all kinds of ecosystem and environmental services. For the purpose of this study, CVM was used to identify-i) the users' WTP for the sustainable management and conservation of the forests and, ii) quantify and convert services into monitory value. CVM involves directly asking people, in a survey, how much they would be willing to pay for specific environmental services (Merrett, 2002). It uses questionnaires to ask people how much they would be willing to pay to increase or enhance the provision of ecosystem services, or alternately, how much they would be willing to accept for its loss or degradation (Pascual et al., 2010).

They are the only available methods to estimate non-use values. The use of surveys allows collecting relevant socio-economic and attitudinal data on the respondents that could be relevant for understanding the variables influencing social preferences and choices. The use of surveys allows estimating hypothetical changes and their impact before they have taken place.

A strong criticism of CVM is that the answers obtained through surveys relying upon hypothetical propositions are subject to a variety of biases (Diamond and Hausman, 1994). The primary sources of bias identified in the literature include : design bias, which involves subjectivity in the establishment of initial bids or payment vehicles; operational bias which refers to unfamiliarity with goods to be valued; hypothetical bias, 
usually an upward bias in WTP-based on the fact that expectations of having to submit an actual payment may not be present; and strategic bias which is related to individuals' intention not to reveal their true preferences, comparable to the free-rider problem (Lesser et al., 1997). However, certain sources of potential bias cannot be entirely removed from the method, each can be controlled to a certain degree through careful study design, allowing for reasonably reliable results (Arrow et al., 1993; Venkatachalam, 2004).

In this study, we were able to estimate the individual's WTP for hypothetical changes in tax for sustainable management and conservation of the forests using the CVM. We minimized the design and operational biases by establishing bids based upon the pre-existing entry fee. Hypothetical bias was addressed by suggesting tax for sustainable management and conservation of the CFs. Strategic bias may be impossible to eliminate as there is no reason to suspect a unidirectional bias in the study.

\section{Econometric model}

The following multiple regression model was developed to find out the relationship between the WTP and the factors affecting the WTP money for the local users (Baral et al., 2008; Khanal et al., 2010).

$\mathrm{WTP}=\beta_{0}+\beta_{1} \mathrm{X}_{1}+\beta_{2} \mathrm{X}_{2}+\beta_{3} \mathrm{X}_{3}+\ldots \ldots \ldots \ldots$ $\ldots+\beta_{\mathrm{n}} \mathrm{X}_{\mathrm{n}}+$ Error,

Where, WTP stands for the local users' WTP money for sustainable management and conservation of the Barandabhar PF (dependent variable); $\beta_{0}$ to $\beta_{\mathrm{n}}$ are parameters to be estimated; and $X_{1}$ to $X_{n}$ are explanatory variables influencing the WTP.

For the local users, Probability (WTP) $=\beta_{0}+\beta_{1}$ Caste $+\beta_{2}$ Gender $+\beta_{3}$ Age $+\beta_{4}$ Education $+\beta_{5}$ Income $+\beta_{6}$ Family size $+\beta_{7}$ Landholding $+\beta_{8}$ Residence type $+\beta_{9}$ Distance + Error
Table 1 : Definition and description of the independent variables for the local users

\begin{tabular}{|l|l|}
\hline Description & $\begin{array}{l}\text { Variable } \\
\text { Type }\end{array}$ \\
\hline HHs' distance from the CFs (minutes) & Scale \\
\hline $\begin{array}{l}\text { No. of HH members } \\
\text { Respondent's age }\end{array}$ & $\begin{array}{l}\text { Scale } \\
\text { Scale }\end{array}$ \\
\hline $\begin{array}{l}\text { Respondent's sex (1=male and } \\
\text { 0=female) } \\
\begin{array}{l}\text { Respondent's ethnicity (1=Brahmin, } \\
\text { 2= Chhetri, 3=Janajati, 4=Dalit) }\end{array}\end{array}$ & $\begin{array}{l}\text { Nominal } \\
\text { Nominal }\end{array}$ \\
\hline $\begin{array}{l}\text { Land holding size owned by a HH } \\
\text { (Kattha; 1 Kattha =0. 007 ha) }\end{array}$ & Scale \\
\hline $\begin{array}{l}\text { Respondent's education-level (years } \\
\text { of school attended) }\end{array}$ & Scale \\
\hline Income of respondent & Scale \\
\hline
\end{tabular}

\section{Results}

\section{Ecosystem goods}

Ecosystem goods prevailing in the study area were identified based on the direct field observation and consultation. The benefits that people are getting from the ecosystem goods were verified with the help of questionnaire. The study identified four ecosystem goods in the study area (Table 2).

Table 2 : Identified ecosystem goods

\begin{tabular}{|c|l|l|}
\hline $\begin{array}{c}\text { S. } \\
\text { N. }\end{array}$ & $\begin{array}{l}\text { Ecosystem } \\
\text { Goods }\end{array}$ & Benefits to the local people \\
\hline 1 & Fuel-wood & $\begin{array}{l}\text { Combustible material for } \\
\text { cooking }\end{array}$ \\
\hline 2 & Fodder & Forage material for livestock \\
\hline 3 & Timber & Building material \\
\hline 4 & NTFP's & Vegetable, medicine \\
\hline
\end{tabular}

\section{Ecosystem services}

Ecosystem services identified during the field visit were verified with the community people. The benefits of each service were identified 
in the same way as done for ecosystem goods identification (Table 3).

Table 3 : Ecosystem services and benefits

\begin{tabular}{|l|l|l|}
\hline $\begin{array}{l}\text { S. } \\
\text { N. }\end{array}$ & $\begin{array}{l}\text { Ecosystem } \\
\text { services }\end{array}$ & Benefits \\
\hline 1. & $\begin{array}{l}\text { Soil } \\
\text { conservation }\end{array}$ & $\begin{array}{l}\text { Prevention from soil } \\
\text { erosion }\end{array}$ \\
\hline 2. & $\begin{array}{l}\text { Oxygen } \\
\text { purification }\end{array}$ & Amelioration of oxygen \\
\hline 3. & $\begin{array}{l}\text { Tourism and } \\
\text { recreation }\end{array}$ & Revenue \\
\hline 4. & Wildlife habitat & Habitat for wild-lives \\
\hline 5. & Aesthetic & Entertainment \\
\hline 6. & $\begin{array}{l}\text { Landscape } \\
\text { beauty }\end{array}$ & Scenic beauty \\
\hline
\end{tabular}

Ranking of the ecosystem goods and services

Numerous ecosystem goods and services provided by the Barandabhar PF were reported to have benefitted the users of the CFs. The respondents were requested to prioritize most promising goods and services based on their preference. Though all the goods and services were important for livelihood, the ranking of the ecosystem goods and services was accomplished on the basis of the weighted mean of the respondents' preferences. Most of the respondent's prioritized timber as their $1^{\text {st }}$ choice (Table 4). However, the maximum average mean (6.3) was found to be on wildlife habitat, which revealed that most of the respondents were aware of the importance of the Barandabhar PF for wildlife habitat; so wildlife habitat was ranked as No. 1. Similarly, this forest had provided large amount of timer to the HHs around the forest; so, timber was ranked as No. 2. Finally, the NTFPs were ranked as No. 8 with least preference.

\section{Monetary value of the forest goods}

MPM was used for estimating the direct use value of the forest goods by the HHs. The major forest goods that are consumed by the local communities include timber, fuelwood and fodder. These goods are obtained through purchase or selfcollection. The study computed the average value of the forest goods consumed in the area based on the estimation of the market price of each of the goods. The sampled HHs (142) were found to have consumed the forest goods (timber, fuelwood and fodder) worth of Nepalese Rupees (NRs. ) 745,000 (US\$ 6,630. 47 @US\$1=NRs 112. 36)per year; the average consumption of forest goods being NRs. 5,246 (US\$ 46. 69) per HH per year. There were, altogether, 2,890 HHs (in both the CFs), and so the total specificuse value was estimated to be NRs. 15,160,940 (US\$134,931.82) per year.

Table 4 : Ranking of the ecosystem goods and services provided by the Barandabhar PF

\begin{tabular}{|c|c|c|c|c|c|c|c|c|c|}
\hline Weight & Preference & Timber & $\begin{array}{l}\text { Fuel- } \\
\text { wood }\end{array}$ & Fodder & \begin{tabular}{|l|} 
Wildlife \\
habitat
\end{tabular} & Tourism & $\begin{array}{c}\text { Fresh } \\
\text { air }\end{array}$ & NTFPs & $\begin{array}{c}\text { Soil conser- } \\
\text { vation }\end{array}$ \\
\hline 8 & $1^{\text {st }}$ choice & 60 & 0 & 0 & 30 & 30 & 22 & 0 & 0 \\
\hline 7 & $2^{\text {nd }}$ choice & 25 & 0 & 5 & 50 & 38 & 20 & 0 & 4 \\
\hline 6 & $3^{\text {rd }}$ choice & 18 & 9 & 12 & 30 & 47 & 23 & 0 & 3 \\
\hline 5 & $4^{\text {th }}$ choice & 7 & 31 & 27 & 17 & 5 & 40 & 0 & 15 \\
\hline 4 & $5^{\text {th }}$ choice & 9 & 19 & 17 & 5 & 2 & 6 & 4 & 80 \\
\hline 3 & $6^{\text {th }}$ choice & 5 & 53 & 20 & 3 & 5 & 8 & 28 & 20 \\
\hline 2 & $7^{\text {th }}$ choice & 8 & 17 & 53 & 7 & 6 & 11 & 30 & 10 \\
\hline 1 & $8^{\text {th }}$ choice & 10 & 13 & 8 & 0 & 9 & 12 & 80 & 10 \\
\hline \multicolumn{2}{|c|}{ Average/Mean } & 6.16 & 3.45 & 3.40 & 6.3 & 6.03 & 5.18 & 1.69 & 3.73 \\
\hline \multicolumn{2}{|c|}{ Rank } & II & VI & VII & I & III & IV & VIII & $\mathrm{V}$ \\
\hline
\end{tabular}




\section{WTP for conservation and sustainable management of forest}

The concerned $\mathrm{CF}$ users were directly asked regarding their WTP money as tax for the conservation and sustainable management of the Barandabhar PF. Majority of the users were found to be willing to pay for better management and conservation of the forest. Out of the total 142 respondents, $78.8 \%$ respondents were ready to pay whereas $21.2 \%$ respondents were not ready to pay. Similarly, $4.5 \%$ respondents were willing to pay below NRs $100 ; 57.1 \%$ were willing to pay NRs, $100-500 ; 27$. $7 \%$ were willing to pay NRs. $501-1,000$ and $10.7 \%$ were willing to pay more than NRs. 1,000 (Figure 2). The WTP of the sampled users for the conservation and sustainable management of the Barandabhar PF was found to be NRs. 65,968 (US\$ 587. 11)per year. The mean WTP was found to be NRs. 589 (US\$5. 24) per HH per year. Majority of the respondents were aware of the importance of the forest. Altogether, there were 2,890 CF users, and the users' WTP was estimated to be NRs. 1,341,153 (US\$ 11,936. 20) per year.

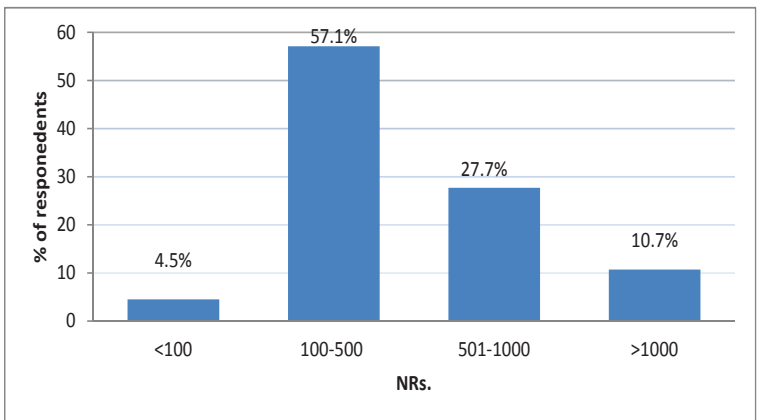

Figure 2 : Willingness to pay for conservation and sustainable management of forest

\section{Multiple regression model}

The following multiple regression models was developed to find out the relationship between the WTP and the factors affecting the WTP for both the users and the visitors (Baral et al., 2008; Khanal et al., 2010).

$\mathrm{WTP}=\beta_{0}+\beta_{1} \mathrm{X}_{1}+\beta_{2} \mathrm{X}_{2}+\beta_{3} \mathrm{X}_{3}+\ldots \ldots \ldots \ldots$ $\ldots+\beta_{\mathrm{n}} \mathrm{X}_{\mathrm{n}}+$ Error,

For the local CF users, Probability (WTP) $=\beta_{0}+\beta_{1}$ ethnicity $+\beta_{2}$ gender $+\beta_{3}$ age $+\beta_{4}$ year of education $+\beta_{5}$ income $+\beta_{6}$ family size $+\beta_{7}$ landholding $+\beta_{8}$ time to reach forest + Error

\section{Results of the multiple regression}

Table 5 shows the results of the multiple regressions on the users' WTP of the users for their efforts on conservation and sustainable management of the forest resources. The gender, income and time to reach the forest were found to be significant $(p \leq 0.05)$ with the users' WTP, which indicated that the income had positive coefficient with the users' WTP where as the gender and time to reach the forest had negative coefficient with the users' WTP. The results showed that the income of the users was found to be significant $(\mathrm{p} \leq 0.05)$ with positive regression coefficient (0.002813), indicating that the users' WTP increased with the increase in the income-level of the local community people. Similarly, the gender was found to be significant $(\mathrm{p} \leq 0.05)$ with negative regression coefficient (-0. 548189), indicating that the users' WTP increased with the increase in the female respondents. Likewise, the time to reach the forest was significant $(\mathrm{p} \leq 0.05)$ with negative regression coefficient (-0. 028548), indicating that the users living far from the forest were less eager to pay for the conservation and sustainable management of the Barandabhar CF than those living near the forest.

Table 5 : Multiple regression model calculation

\begin{tabular}{|l|r|r|r|r|}
\hline Variable & Coefficient & Std. Error & z-Statistic & Prob. \\
\hline Ethnicity & -0.105082 & 0.222478 & -0.472326 & 0.6367 \\
\hline Family size & -0.093586 & 0.167079 & -0.560134 & 0.5754 \\
\hline Gender & -0.548189 & 0.448339 & -1.222713 & 0.0314 \\
\hline Income & 0.002813 & 0.001475 & 1.907852 & 0.0264 \\
\hline Landholding & 0.059609 & 0.070794 & 0.841997 & 0.3998 \\
\hline Time to reach forest & -0.028548 & 0.014335 & -1.991513 & 0.0464 \\
\hline Year of education & 0.004800 & 0.051107 & 0.093912 & 0.9252 \\
\hline Age & 1.562174 & 1.374900 & 1.136209 & 0.2559 \\
\hline McFadden $\mathrm{R}^{2}$ & 0.092056 & \multicolumn{2}{|c|}{ Total observations = 142 } & \\
\hline
\end{tabular}




\section{Discussion}

The total WTP of the users for the conservation and sustainable management of Barandabhar PF by the local community forest users was calculated as NRs. 1,341,153 (US\$ 11,936. 20). Similarly, the study conducted by Bhandari et al. (2018) in the Panchase PF showed the users' WTP for its sustainable use and management to be NRs. 52. 2 million (US\$ 521,930. 00). The economic value of the Barandabhar PF is significantly less as compared to that of the Panchase Protected Forest. It could be due to the reason that the users of the Panchase PF might have received more ecosystem services than the Barandabhar PF users. Besides, it could be due to more wildlife conflict in the Barandabhar PF than in the Panchase PF. The estimated specific use value of the Barandabhar PF was NRs. 15,160,940 (US\$134,931. 82) per year. We did not find any literature to compare our findings on the monitory value of the goods of this PF with those of the other protected forests of Nepal. However, Pant et al. (2012) estimated the value of the provisioning services (the goods from the forests used directly or indirectly) from the Kangchenjunga landscape to be NRs. 7. 01 billion (approx. US\$ 98 million) per year, which is more than that from the Barandabhar PF. The reason could be that the Kangchenjunga landscape possess a large amount of forest goods like wood, timber and, especially, NTFPs as compared to the ones possessed by the Barandabhar PF.

In this study, income, distance and gender were found to be the factors affecting the WTP of the users. The results of the multiple regression showed that the users' WTP decreased as per the decrease in the proximity of the users' HHs from the forest. This indicated that the users living near the forest were more willing to pay as compared those living far from the forest for the conservation and sustainable management of the Barandabhar PF. In terms of gender, the women were found to be more willing to pay as compared to the men. This might be because the women had to spend more time in domestic chores such as collecting grass, firewood, fodder, bedding materials, etc. from the forests. Similarly, the users' WTP increased with the increase in their income. These findings are consistent with those of Bhandari et al. (2018) and KC et al. (2010).

\section{Conclusion}

The Barandabhar PF has provided numerous ecosystem goods and services to the people living around the forest. Additionally, this PF has also provided significant opportunity for tourism and recreation. Thus, integrated evaluation of this PF along with its ecological and economic value is required for the conservation and sustainable management of its forest resource. The estimated specific-use value of the Barandabhar PF was found to be NRs. 15,160,940 (US\$134,931. 82) per year. The estimated total WTP value for the conservation and sustainable management of this PF was NRs. 1,341,153 (US\$ 11,936. 20); the average users' WTP value for the purpose being NRs. 589 (US\$ 5. 24) per HH per year. These results show that there is significant opportunity for the payment for ecosystem services in the Barandabhar PF.

The results of regression revealed that the users with high income were willing to contribute more for the conservation and sustainable management of the forest as compared to those with low income as the latter have to spend almost all their income just for their subsistence livelihood. These findings suggest that forest management interventions are needed to increase the income of the poor users. Similarly, time to reach the forest was found to have negative relationship with the uses' WTP; the WTP of the users living near the forest was found to be higher than that of those living far from the forest. This could be due to the higher opportunity of benefits to the users living close to the forests. So, the concerned forest user committee should emphasize to distribute the benefits among all the users in equitable manner. In addition, the $\mathrm{CF}$ users are likely to be further benefited from the sustainable management of their CFs. However, the concerned forest user committee should emphasize on distributing the benefits to all the CF users in equitable manner. Our study revealed that the women were more willing to pay for the ecosystem services provided by the Barandabhar $\mathrm{PF}$ as compared to the men. This indicates that women's participation in the conservation and management of the forests in the rural areas is likely to increase the value of the forests as their WTP is higher than that of men. Therefore, the policy makers and the concerned stakeholders should consider significant involvement of women in forest conservation and management programs. 
References

Arrow, K., Solow, R., Portney, P. R, Leamer,E. E, Radner, R. and Schuman, H. 1993. Report of the NOAA Panel on Contingent Valuation. National Oceanic and Atmospheric Administration, Washington, D. C.

Baral, N., Stern, M. J., and Bhattarai, R. 2008. Contingent valuation of ecotourism in Annapurna conservation area, Nepal : Implications for sustainable park finance and local development. Ecological Economics 60 : 218-227.

Barbier, E. B., Baumgärtner, S., Chopra, K., Costello, C., Duraiappah, A., Hassan, R., Kinzig, A., Lehman, M., Pascual, U., Polasky, S., Perrings, C., 2009. The valuation of ecosystem services, Chapter 18. In Biodiversity, Ecosystem Functioning, and Human Wellbeing : An Ecological and Economic Perspective. Edited by Shahid Naeem, Daniel E. Bunker, Andy Hector, Michel Loreau, and Charles Perrings. Oxford : Oxford University Press. : 248-62.

Bhandari, A. R., Khadka, U. R., and Kandel, K. R. 2018. Valuation of Ecosystem Services : A case of Panchase Protected Forest in the midhill of Western Nepal. Tribhuvan University, Central Department of Environmental Science, Kathmandu, Nepal. Asian Journal of Science and Technology 09 : 7591-7595.

Diamond, Peter A. and Hausman,J. A. 1994. "Contingent Valuation : Is Some Number Better than No Number?" Journal of Economic Perspectives 8 (4) : 45-64.

Groot, R. D., Wilson, M. A. and Boumans, R. M. J. 2002. A typology for the classification, description and valuation of ecosystem functions, goods and services. Ecological Economics 41 (3) : 393-408.

KC, B., Kandel, P. N. and Adhikari, S. 2010. Economic valuation of ecosystem services in protected areas : A case study from Nepal. Banko January 23 : 1.

Kumar, M. and Kumar, P. 2002. Valuation of the ecosystem services, a psycho-culture perspective. Ecological Economics 4 : 808-819.
Lesser, J. A., Dodds, D. E. and Zerbe, R. O. 1997. Environmental economics and policy. Addison and Wiley Longman, Inc. New York, USA.

Merrett, S. 2002. Deconstructing households' willingness-to-pay for water in low-income countries. Water Policy 4 : 157-172.

MEA. 2005. Ecosystems and Human Wellbeing : Synthesis. Millennium Ecosystem Assessment, Island Press, Washington D. C.

Pant, K. P., Rasul, G., Chhetri, N., Rai, R. K. and Sharma, E. 2012. Value of Forest Ecosystem Services : A Quantitative Estimation from the Kangchenjunga Landscape in Eastern Nepal. ICIMOD Working Paper 2012/5. Kathmandu, Nepal.

Pascual, U. and Muradian, R. 2010. The economics of valuing ecosystem services and biodiversity. In The Economics of Ecosystems and Biodiversity : Ecological and Economic Foundations (ed) Kuman, P. London/Washington : Earthscan.

Powell, I., White, A. and Landell-Mills, N. 2002. Developing markets for the ecosystem services of forests. Forest Trends, Washington D. C.

Singh, S. P., Negi, G. C. S., Pant, M. C. and Singh, J. S. 2002. Economic consideration in the central Himalayan agro-ecosystems. Centre for Science and Forests, New Delhi.

Venkatachalam, L. 2004. The contingent valuation method : A review. Environmental Impact Assessment Review 24 : 89-124.

Villegas-Palacio, C., Berrouet, L., Connie, L., Ruiz, A., and Upegui, A. 2016. Lessons from the integrated valuation of ecosystem services in a developing country : Three case studies on ecological, socio-cultural and economic valuation. Ecosystem Services 22 (2016) : 297-308. http : //dx. doi. org/10. 1016/j. ecoser. 2016. 10. 017 